\title{
Pengembangan Model Pembelajaran Sains, Technology, Art, Engineering And Mathemathic Pada Kurikulum PAUD
}

\author{
Sri Wahyuni ${ }^{1}$, Reswita ${ }^{2}$, Mar'atul Afidah ${ }^{3}$ \\ PG-PAUD Universitas Lancang Kuning ${ }^{1,}$ PG-PAUD Universitas Lancang Kuning ${ }^{2}$, Pendidikan \\ Biologi Universitas Lancang Kuning ${ }^{3}$ \\ Email: sriwahyuni91@unilak.ac.id ${ }^{1}, \underline{\text { reswita@unilak.ac.id }}{ }^{2}, \underline{\text { maratul@unilak.ac.id }}{ }^{3}$
}

\begin{abstract}
Abstrak
Pembelajaran Science, Technology, engineering, Art and Mathematic (STEAM) memiliki efek positif pada pembelajaran anak. Metode STEAM dalam pembelajaran mampu melatih peserta didik baik secara kognitif, keterampilan, maupun afektif. Tujuan yang akan dicapai melalui penelitian ini adalah tersusunnya sebuah model pembelajaran bermuatan STEAM yang dapat diterapkan di satuan PAUD. Metodologi penelitian yang digunakan adalah desain penelitian pengembangan atau research and development dengan responden pengelola dan guru PAUD di Kecamatan Rumbai Pesisir. Berdasarkan keseluruhan hasil kuesioner disimpulkan bahwa indikator yang menjadi tolok ukur keterbacaan kurikulum bermuatan STEAM. Terjadi peningkatan pengetahuan dan pemahaman guru setelah dilakukan ujicoba operasional model pengembangan kurikulum PAUD berbasis STEAM pada subjek penelitian yang telah dilakukan.
\end{abstract}

Kata kunci: Pembelajaran STEAM, Kurikulum PAUD, Pengembangan Model

\begin{abstract}
Learning Science, Technology, engineering, Art and Mathematics (STEAM) has a positive effect on children's learning. STEAM Method in learning is able to train students both cognitively, skills and affective. The goal to be achieved through this research is the preparation of a STEAMcharged learning model that can be applied in PAUD units. The research methodology used is the design of research development or research and development with respondents of managers and PAUD teachers in Rumbai Pesisir District. Based on the overall results of the questionnaire it was concluded that the indicators that measure the readability of the curriculum contained STEAM. There has been an increase in teacher knowledge and understanding after an operational trial of the STEAM-based PAUD curriculum development model on the research subjects that have been conducted.
\end{abstract}

Keywords: STEAM Learning, PAUD Curriculum, Model Development 


\section{PENDAHULUAN}

Pemahaman yang baik tentang bidang teknologi harus ditanamkan sejak dini, sehingga dapat memberikan bekal bagi anak untuk bersaing dengan perkembangan tekhnologi yang begitu pesat. Kedepan teknologi akan memegang peranan yang sangat vital bagi perkembangan dunia. Disadari bahwa teknologi akan memudahkan aktivitas manusia dalam memenuhi kepuasan hidupnya. Berbagai hasil penelitian menyebutkan bahwa masa usia dini merupakan periode emas bagi perkembangan anak dimana 50\% perkembangan kecerdasan terjadi pada usia 0-4 tahun, 30\% berikutnya hingga usia 8 tahun. Periode emas ini sekaligus merupakan periode kritis bagi anak dimana perkembangan yang didapatkan pada periode ini sangat berpengaruh terhadap perkembangan pada periode berikutnya hingga masa dewasanya. Periode ini hanya datang sekali dan tidak dapat ditunda kehadirannya, sehingga apabila terlewat berarti habislah peluangnya, (Sugeng et al., 2019). Dengan demikian, seiring perkembangan teknologi dan industri maka sangat perlu dikembangkan pendidikan yang berbasis STEAM (Science, Technology, Engineering, Arts and Mathematics).

Saat ini STEAM dijadikan dasar metode pembelajaran sehingga nilai-nilai yang ditanamkan dalam proses pembelajaran mengacu kepada perkembangan dunia teknologi secara komprehensif. Metode STEAM dapat diaplikasikan sejak dini dengan mengkolaborasikan relasional antar ilmu pengetahuan yang berdampingan dengan kehidupan sehari hari melalui integrasi antar komponen yang ada dalam tema-tema dalam satu tahun ajaran. Pendidikan anak usia dini merupakan salah satu bentuk penyelenggaraan pendidikan yang menitikberatkan pada peletakan dasar ke arah pertumbuhan dan 6 (enam) perkembangan: agama dan moral, fisik motorik, kognitif, bahasa, sosial-emosional, dan seni, sesuai dengan keunikan dan tahap-tahap perkembangan sesuai kelompok usia yang dilalui oleh anak usia dini (Kementerian Pendidikan dan Kebudayaan Republik Indonesia, 2014). Penelitian yang dilakukan oleh (Becker \& Park, 2011) menunjukkan bahwa pendekatan STEAM memiliki efek positif pada pembelajaran peserta didik. Metode STEAM dalam pembelajaran mampu melatih peserta didik baik secara kognitif, keterampilan, maupun afektif, selain itu peserta didik tidak hanya diajarkan secara teori saja, tetapi juga praktik sehingga peserta didik mengalami langsung proses pembelajaran, (Septiani \& Yuliarto, 2016). Perkembangan kognitif anak usia dini, masih memerlukan visualisasi dalam proses transfer knowledge, hal inilah diperlukan dalam proses pembelajaran diperlukan media/ alat bantu yang menarik untuk merangsang perkembangan motorik anak. Salah satu yang dapat dikembangkan adalah dengan alat permainan edukatif bermuatan STEAM.

Dari pengamatan yang dilakukan oleh tim pengembang bahwa pola pembelajaran anak usia dini masih belum berkembang secara optimal, hal ini ditandai dengan belum adanya kurikulum yang membangkitkan jiwa sains pada anak usia dini. Masih berkutat pada nyanyian dan permainan yang kurang edukatif, sehingga anak mudah bosan dan cenderung bermain sendiri. Hal ini mengakibatkan penanaman struktur kognitif dan motorik anak tidak berkembang secara 
komprehensif. Hasil wawancara yang dilakukan beberapa kepala sekolah di TK dan PAUD, bahwa kepala sekolah mengakui kurangnya pengetahuan guru dalam mengoptimalkan tumbuh kembang struktur kognitif dan motorik anak. Hal ini dikarenakan kemampuan guru-guru memahami STEAM dan penerapannya bisa dikategorikan kurang mampu. Berdasarkan uraian tim peneliti merasa penting untuk melakukan penelitian mengenai pengembangan model pembelajaran bermuatan STEAM pada anak usia dini

\section{METODE PENELITIAN}

Adapun penelitian ini menggunakan penelitian deskriptif dengan pendekatan kuantitatif yaitu kegiatan dalam penelitian deskriptif dalam kerangka penelitian pengembangan (Research and Development). Tempat penelitian yaitu direncanakan pada Kota Pekanbaru. Direncanakan yang menjadi populasi dalam penelitian yaitu seluruh PAUD di Kota Pekanbaru, dengan penentuan sampel menggunakan area sampling (area per kecamatan) sehingga diperoleh 12 Satuan PAUD yang akan dijadikan sampel dan tempat ujicoba model. Alat pengumpul data berupa angket yaitu kuesioner dan dokumentasi. Penelitian ini akan dilakukan pada bulan Januari tahun 2020 di HIMPAUDI Kecamatan Rumbai Pesisir. dengan karakteristik responden merupakan Pengelola dan Guru PAUD di Kecamatan Rumbai Pesisir. Alat yang digunakan untuk mengumpulkan data dalam penelitian ini adalah angket untuk mengukur keberhasilan produk (kurikulum bermuatan STEAM di lembaga PAUD). Pengolahan data dilakukan setelah semua data terkumpul melalui angket. Data yang telah terkumpul diolah dengan langkah-langkah sebagai berikut: Memeriksa kelengkapan isian data instrumen yang telah diterima dari sampel penelitian, Membuat tabel pengolahan data, Menskor dan menghitung jumlah jawaban responden serta memasukan dalam tabel pengolahan, Menganalisis data yang telah diperoleh. Setelah data diolah ditetapkan kriteria penilaian masing-masing data yang diperoleh yang mengacu pada batasan yang dikemukakan oleh (Riduwan, 2007) pengelompokkan kriteria pengolahan data adalah sebagai berikut:

Tabel Kriteria Pengolahan Data Variabel

\begin{tabular}{|c|c|}
\hline Persen & Kategori \\
\hline $81-100 \%$ & Sangat Tinggi \\
\hline $61-80 \%$ & Tinggi \\
\hline $41-60 \%$ & Cukup Tinggi \\
\hline $21-40 \%$ & Sedikit \\
\hline $0-20 \%$ & Hampir tidak ada \\
\hline
\end{tabular}

\section{HASIL DAN PEMBAHASAN}


Gambaran umum Naskah Kurikulum kurikulum berbasis STEAM dapat diuraikan secara singkat mengenai model dan produk yang menyertainya, yaitu Model kurikulum berbasis STEAM. Penilaian dilakukan secara konsisten, sistematik dan terprogram dengan menggunakan tes dalam bentuk tertulis ataupun secara lisan dan nontes dalam bentuk pengamatan kerja, pengukuran sikap, penilaian hasil karya, proyek/produk, portofolio dan penilaian diri.

Hasil studi lapangan yang diperoleh melalui pengisian angket dari pendidik dan kepala sekolah mengenai model kurikulum berbasis STEAM

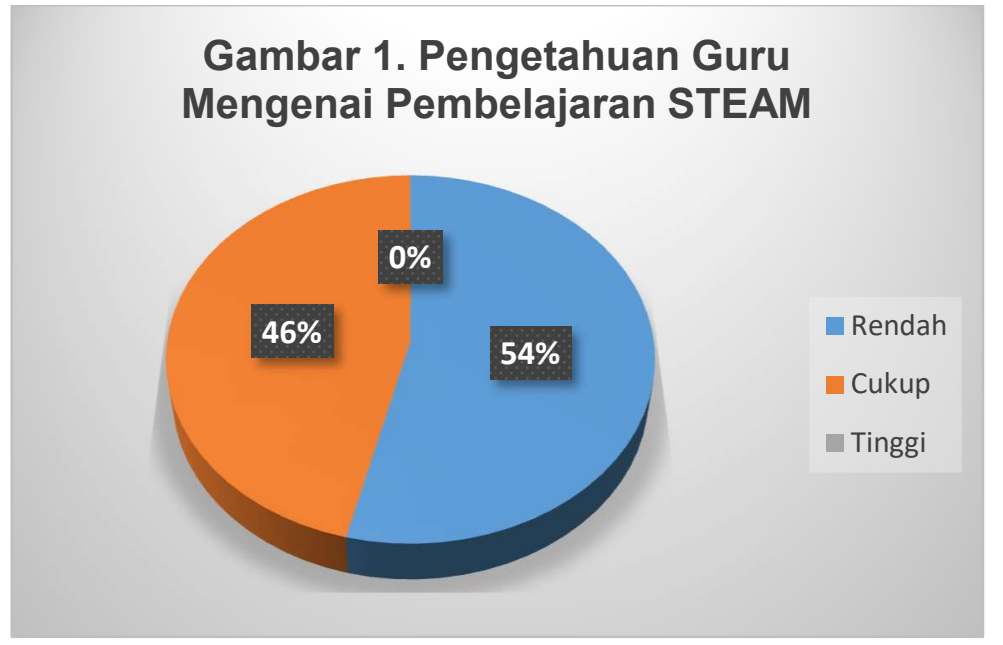

Gambar 1. Pengetahuan Guru Mengenai Pembelajaran STEAM

Dari gambar 1 di atas disimpulkan bahwa pengetahuan guru mengenai model kurikulum berbasis STEAM 54\% masih rendah. Dan tidak ada guru yang benar-benar memahami mengenai model kurikulum berbasis STEAM.

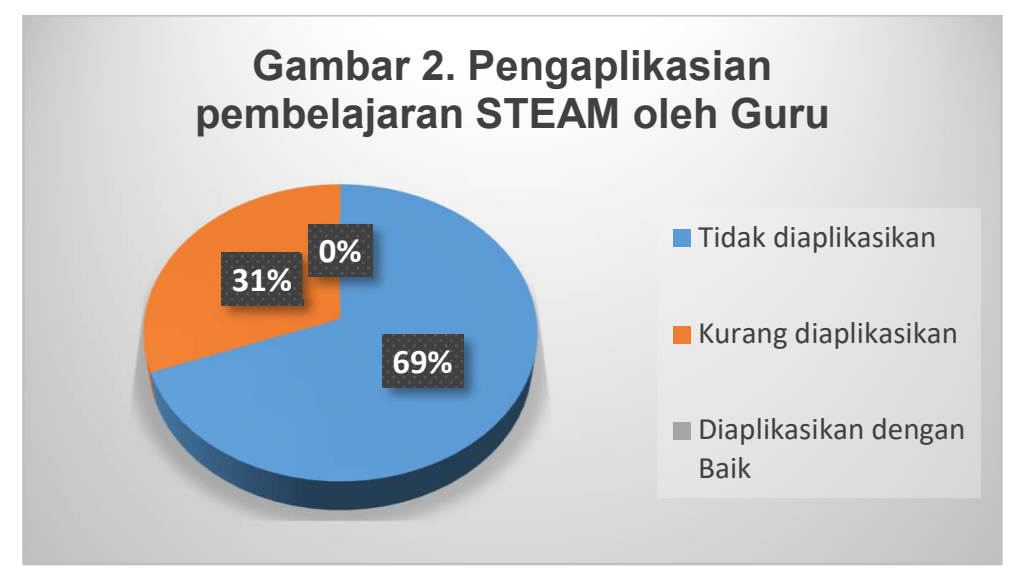

Gambar 2. Pengaplikasian Pembelajaran STEAM oleh Guru 
Berdasarkan gambar 2 dapat disimpulkan bahwa pengaplikasian model kurikulum berbasis STEAM oleh guru belum dilaksanakan. Ini terlihat dari 69\% dari responden tidak mengaplikasikan model kurikulum berbasis STEAM di sekolah.

\section{Gambar 3. Persepsi Guru mengenai kebermanfaatan Pembelajaran \\ STEAM}

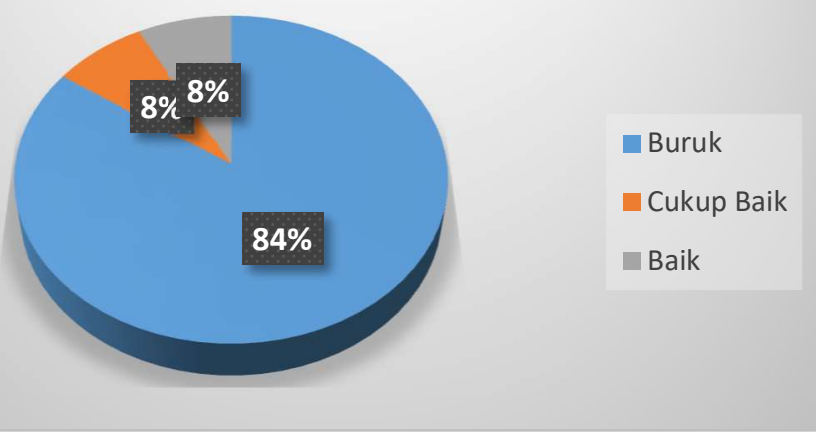

Gambar 3. Persepsi Guru Mengenal Kebermanfaatan Pembelajaran STEAM

Berdasarkan gambar 3, persepsi guru mengenai kebermanfaatan model kurikulum berbasis STEAM rata rata $84 \%$ guru mengatakan belum merasakan manfaatnya.

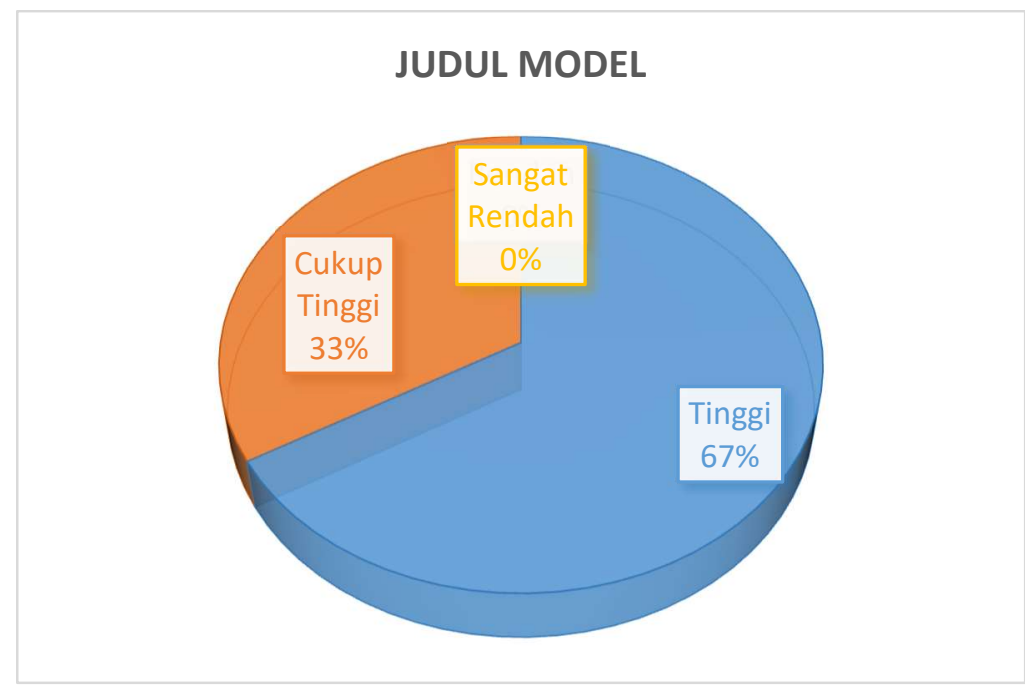

Gambar 4. Judul Model Pembelajaran STEAM

Berdasarkan diagram di atas, keseluruhan indikator yang menjadi tolok ukur kesesuaian judul model dengan pelaksanaannya pada saat uji operasional di ketiga lembaga 67\% guru menyatakan tingkat kesesuaian judul dengan uji coba operasional adalah tinggi dan tidak ada guru yang menyatakan judul model tidak sesuai dengan pelaksanaan uji operasional yang telah dilaksanakan. 


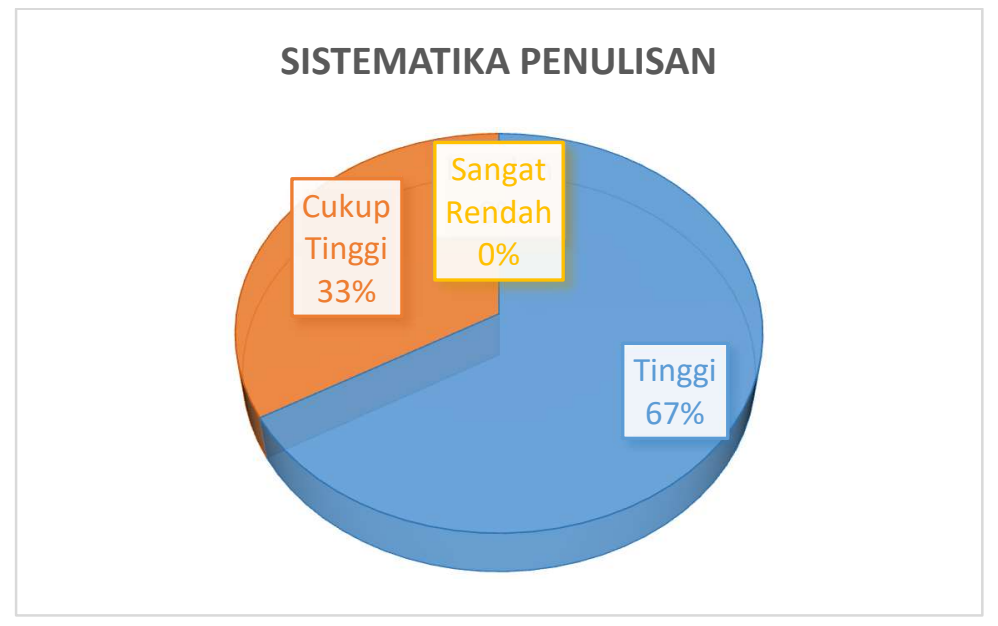

Gambar 5. Sistematika Penulisan

Berdasarkan diagram di atas, sistematika penulisan Naskah Kurikulum sudah baik. Indikator yang menjadi tolok ukur kesesuaian sistematika penulisan model dengan pelaksanaannya pada saat uji operasional di ketiga lembaga 67\% guru menyatakan tingkat kesesuaian adalah tinggi.dan tidak ada guru yang menyatakan sistematika penulisan Naskah Kurikulum tidak sesuai dengan pelaksanaan uji operasional yang telah dilaksanakan.

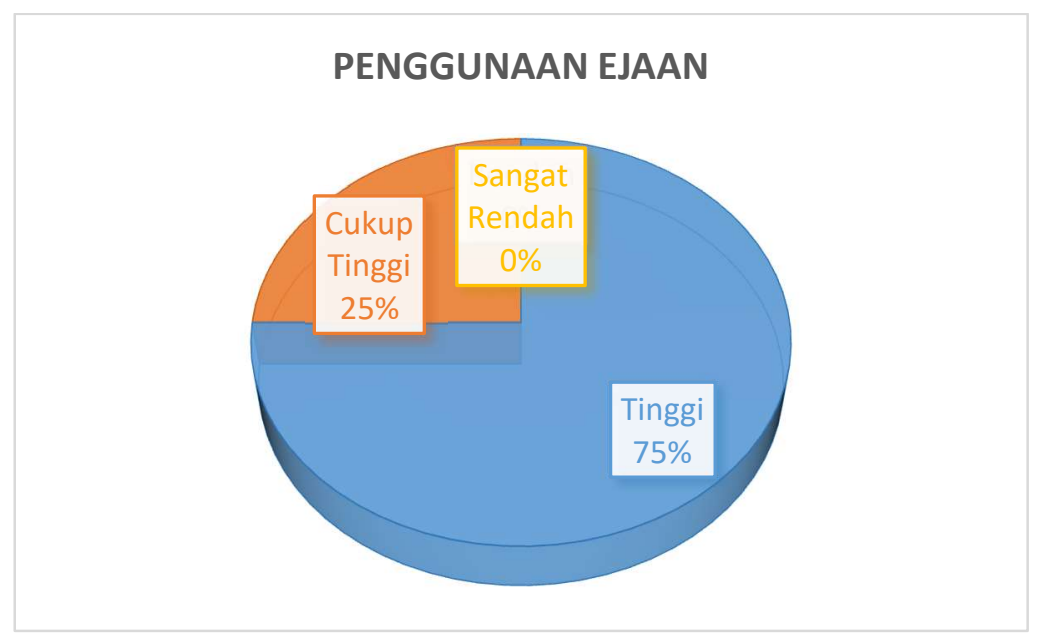

Gambar 6. Penggunaan Ejaan

Berdasarkan diagram di atas, keseluruhan indikator yang menjadi tolok ukur kesesuaian penggunaan ejaan dalam Naskah Kurikulum dengan pelaksanaannya pada saat uji operasional di ketiga lembaga 75\% guru menyatakan tingkat kesesuaian judul dengan uji coba operasional adalah tinggi dan 50\% cukup tinggi. Artinya, tidak ada guru yang menyatakan penggunaan ejaan model tidak sesuai dengan pelaksanaan uji operasional yang telah dilaksanakan. 


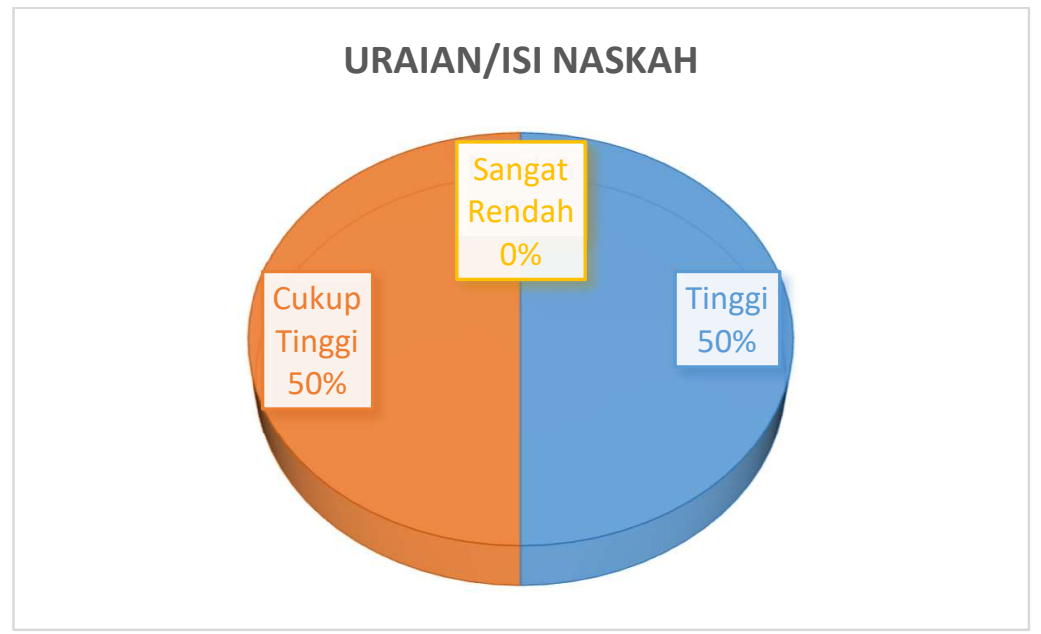

Ganbar 6. Uraian dan Isi Naskah

Pada indikator kesesuaian uraian/isi Naskah Kurikulum dengan pelaksanaan uji operasional di lapangan, 50\% guru menyatakan cukup tinggi dan tinggi. Atau tingkat kesesuaiannya adalah tinggi. Termasuk pemahaman guru terhadap isi naskah. Tidak ada guru yang menyatakan naskah perlu diulang atau perlu direvisi secara keseluruhan pada aspek uraian/isi Naskah Kurikulum.

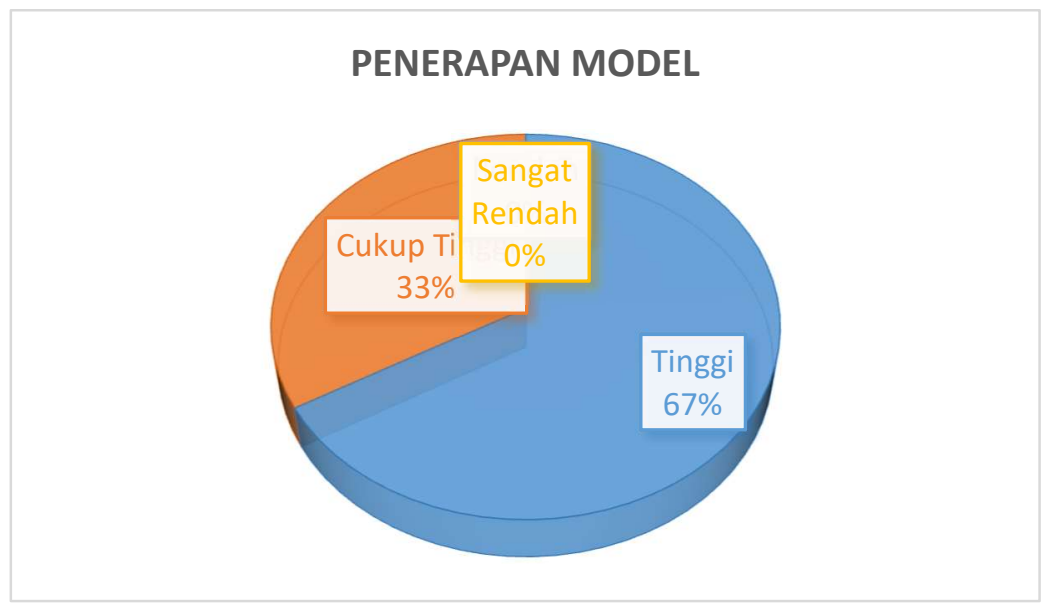

Gambar 7. Penerapan Model

Penerapan model mencakup kemudahan guru dalam penerapan model, kelayakan dan kesesuaian penerapan model dengan proses Pembelajaran bermuatan STEAM. dari hasil uji operasional anak yang mengatakan kesesuaian penerapan model sangat tinggi yaitu sebanyak 67\% dan tidak ada guru yang mengalami kesulitan yang berarti dalam pelaksanaan dan penerapan model pembelajaran bermuatan STEAM. 


\section{Hasil Ujicoba Model Konseptual dan Operasional}

Uji coba model kurikulum berbasis STEAM di Kecamatan Rumbai Pesisir. Peserta uji coba adalah tim peneliti, pengelola lembaga pendidikan anak usia dini dan peserta didik. Sebelum peneliti bersama pengelola dan guru mengimplementasikan model pelatihan yang sudah disusun, guru diobservasi mengenai pemahaman guru terhadap pembelajaran STEAM, guru dalam menerapkan pembelajaran berbasis STEAM. Kemudian dilaksanakan pembelajaran berbasis STEAM dengan menggunakan RPPH yang sudah dirancang. pada saat uji coba berlangsung, peneliti melakukan observasi dan monitoring untuk mendapatkan data yang dapat dimanfaatkan untuk menyempurnakan kurikulum.

Setelah pelaksanaan uji konseptual, guru di wanwancara kembali untuk mengukur pemahaman mereka setelah mengikuti pembelajaran. Hal-hal yang diobservasi dan dimonitoring meliputi: Kemampuan pengelola dan guru dalam mengimplementasikan pembelajaran berbasis STEAM, Aktivitas pengelola dan guru selama uji coba model pembelajaran berbasis STEAM., Tanggapan pengelola dan guru terhadap pelaksanaan hasil uji coba model pembelajaran berbasis STEAM dan Kemudahan dan kesulitan yang dihadapi pengelola dan guru serta anak usia dini pada saat uji coba pembelajaran berbasis STEAM.

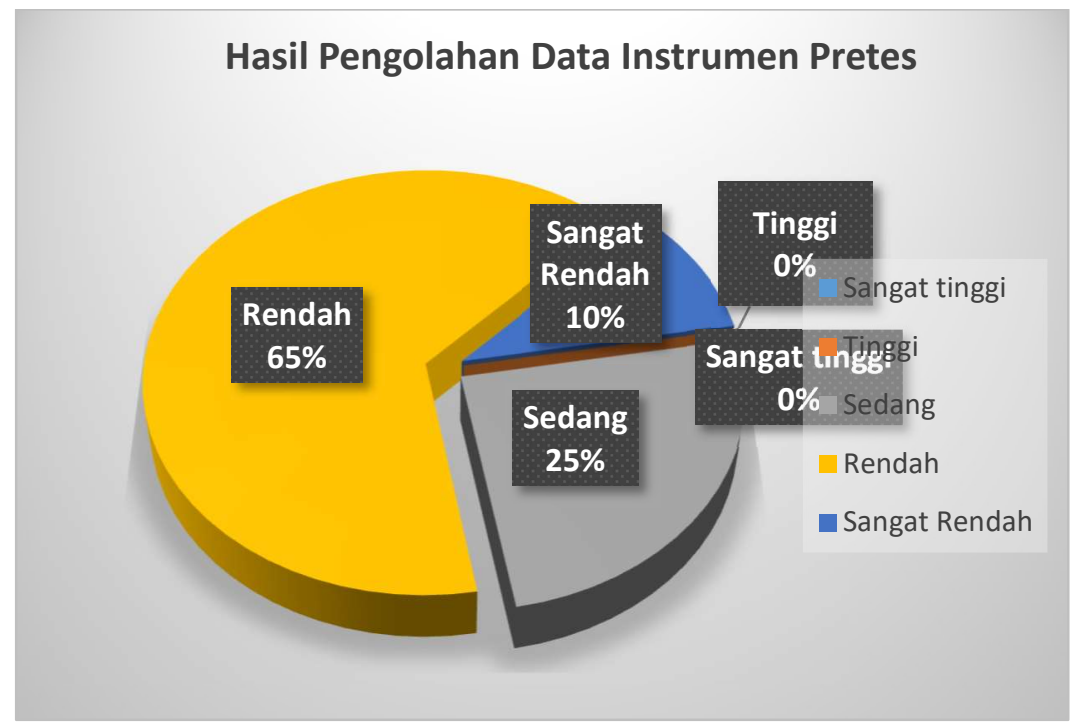

Gambar 8. Hasil Pengolahan Data Instrumen Pretes

Sebelum dilaksanakan pembelajaran, guru mengisi questioner terlebih dahulu melalui wawancara oleh tim peneliti untuk mengukur tingkat pemahaman dan kompetensi guru dalam pembelajaran bermuatan STEAM. Adapun hasil yang diperoleh adalah 65\% dari keseluruhan guru memiliki tingkat pemahaman mengenai pembelajaran bermuatan STEAM adalah rendah. $25 \%$ lainnya berada pada kategori sedang, 10 \% guru berada pada kategori sangat rendah, dan tidak ada guru yang berada pada kategori tinggi dan sangat tinggi. 
Berdasarkan hasil pretest dapat disimpulkan bahwa rata-rata guru perlu mengikuti pembelajaran pembelajaran bermuatan STEAM pada anak usia dini.

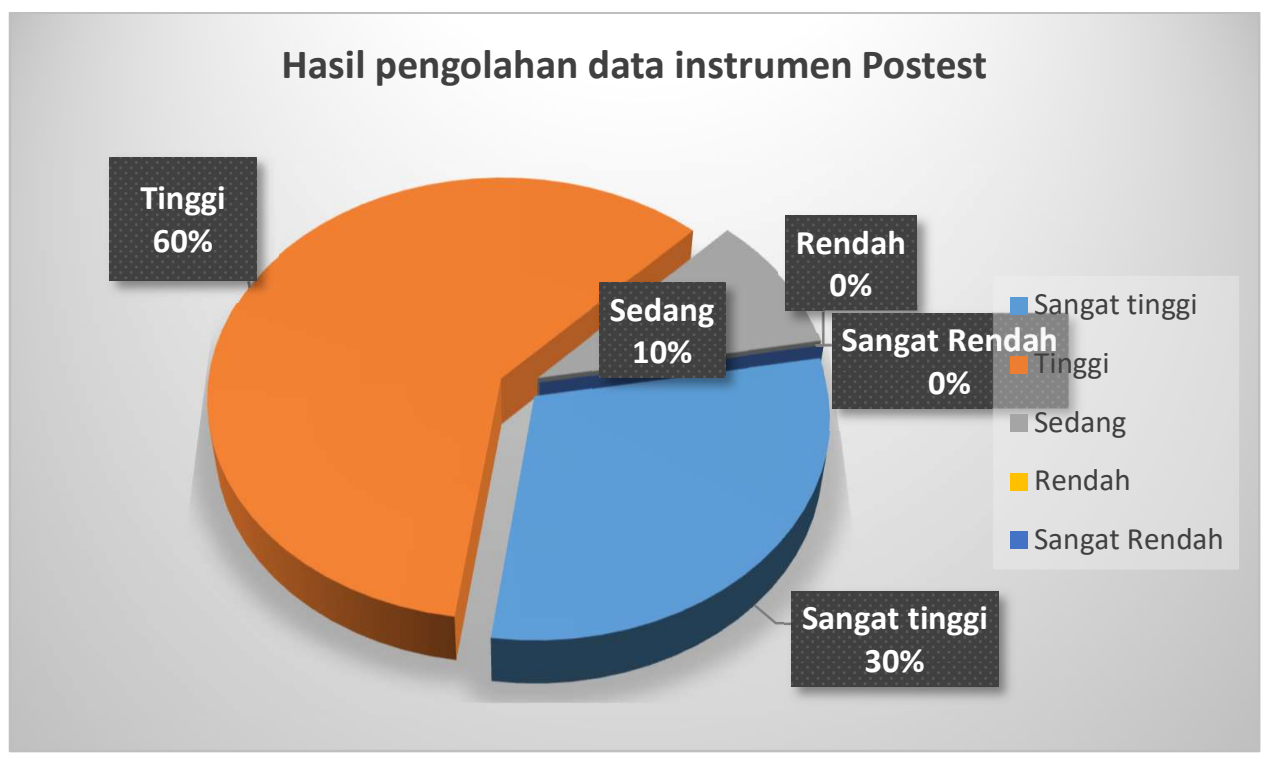

Gambar 9. Hasil Pengolahan Data Instrumen Pistest

Setelah pelaksanaan orientasi teknis dan pembelajaran maka diperoleh hasil yang memuaskan. Hal ini ditunjukkan dari hasil postest yang menunjukkan bahwa $60 \%$ guru memiliki kemampuan dan pemahaman yang tinggi dalam pembelajaran bermuatan STEAM. Hanya 10\% di antaranya yang masih pada kategori rendah. Untuk melihat perbandingan hasil pretes dan postest silahkan lihat grafik berikut:

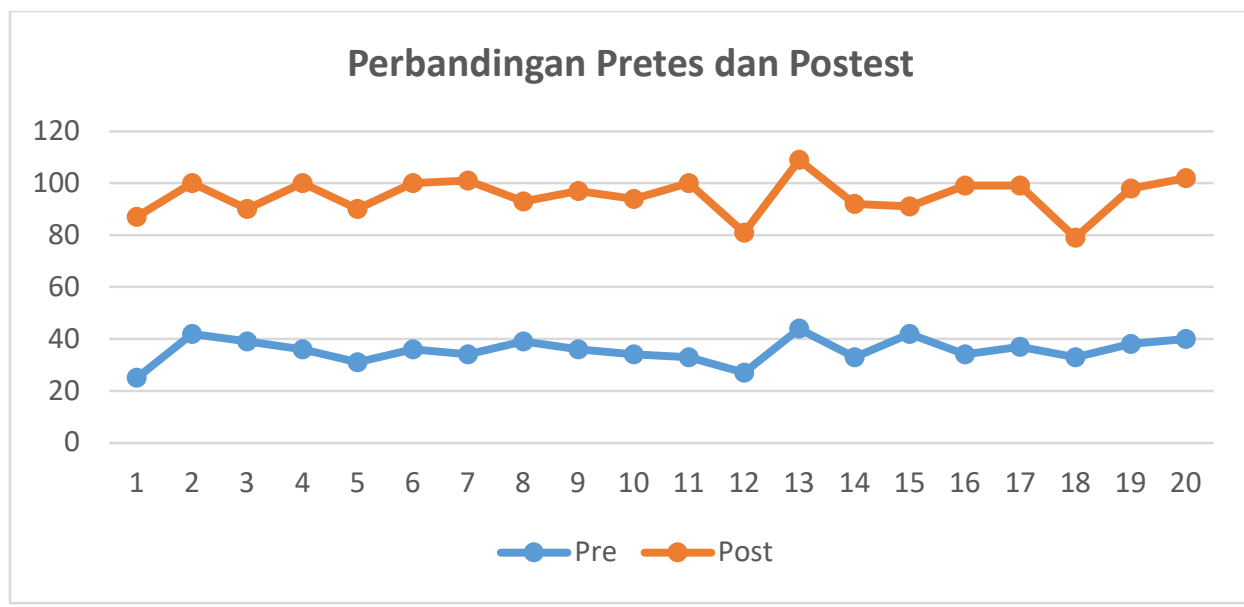

Gambar 10. Hasil Perbandingan Pretest dan Postest

Dari hasil analisis data, maka disimpulkan bahwa terdapat perubahan dan peningkatan secara signifikan pemahaman guru sebelum dan sesudah dilaksanakannya penerapan model. Berdasarkan grafik di atas, semua indikator/materi pembelajaran meningkat dari sebelum Pengembangan Model Pembelajaran (Wahyuni, Reswita,Afidah) 305 
pemberian perlakuan sampai dengan setelah diterapkannya pembelajaran bermuatan STEAM pada anak usia dini.

Adapun studi dokumentasi di beberapa kegiatan inti yang dilakukan pada saat penelitian menggunakan kurikulum STEAM:

Hasil Uji Beda (T test) pretest dan postest uji operasional

Tabel 1 Paired Samples Correlations

\begin{tabular}{|ll|r|r|r|}
\hline & \multicolumn{1}{|c|}{ N } & \multicolumn{1}{c|}{ Correlation } & \multicolumn{1}{c|}{ Sig. } \\
\hline Pair 1 & Pretest \& Postest & 80 &, 924 &, 000 \\
\hline
\end{tabular}

Berdasarkan pengolahan data menggunakan SPSS 20.00 dapat disimpulkan bahwa terdapat perbedaan yang signifikan pengetahuan guru antara sebelum dengan sesudah mengikuti model kurikulum berbasis STEAM 0.924 (92.4\%) pada $\alpha=0.05$. Beberapa guru yang menjadi subjek studi pendahululuan di lapangan menuliskan bahwa mereka kurang mengetahui pembelajaran PAUD bermuatan STEAM. Pada item pernyataan Guru memahami makna masingmasing bagian STEAM (Science, Technology, Enginering, Art and Mathematic), dapat disimpulkan dari beberapa jawaban mereka adalah cukup tahu yaitu: STEAM merupakan metode pengajaran yang melibatkan siswa sebagai penanggungjawab, belajar Seni matematik serta sains untuk anak, dan pembelajaran yang mengenalkan anak dengan alam. sementara untuk pemahaman mengenai engineering dan technology belum dipahami. Menurut (DeJarnette, 2018), "STEAM (Science, Technology, Engineering, Art, and Math) education has received growing attention over the past decade, primarily within the middle and high school levels". Manfaat STEAM yaitu dapat meningkatkan pembelajaran yang lebih aktif dan meningkatkan motivasi siswa.

Hasil akhir yang diharapkan dari penerapan metode STEAM adalah siswa yang mengambil risiko serius, terlibat dalam pembelajaran pengalaman, bertahan dalam pemecahan masalah, merangkul kolaborasi, dan bekerja melalui proses kreatif. Selain itu, dalam metode STEAM, guru bertindak sebagai fasilitator, dan siswa adalah pusat/sentral dari proses pembelajaran, baik di dalam atau di luar kelas. Pendekatan STEAM mengedepankan pembelajaran kolaboratif. Maka dari itu, ruang kelas harus didesain khusus untuk menghasilkan suasana belajarmengajar yang interaktif dan menyenangkan. Kursi dan meja tidak disusun secara berderet dan kaku, melainkan dapat dipindahkan secara fleksibel sesuai kebutuhan belajar siswa, (Apriliana et al., 2018). Ini didorong oleh kebutuhan siswa yang seringkali berkelompok untuk mengerjakan proyek bersama.

Dalam bidang Science (Sains), siswa dituntut untuk mampu menggunakan pendekatan scientific method dalam menyelesaikan suatu masalah dalam kehidupan sehari-hari. Dibidang Technology (Teknologi), siswa akan berkolaborasi dalam penggunaan teknologi baik untuk mengolah data maupun menyampaikan informasi yang mereka dapatkan. 
Bidang Engineering (Teknik), siswa akan mengkolaborasikan hasil temuannya guna menciptakan suatu produk atau dapat pula mencari solusi-solusi yag tepat. Sedangkan dalam bidang Arts (Seni), siswa akan mengkreasikan produk / temuan mereka agar dapat diterima oleh masyarakat ataupun bagaimana cara mereka mempromosikan hasil temuan tersebut. Selanjutnya adalah dalam bidang Mathematics (Matematika), siswa akan mengunakan pendekatan matematika dalam mengolah data yang mereka dapatkan, (Nurhikmayati, 2019).

Dalam pembelajaran Matematika sendiri, pembelajaran STEAM dapat diaplikasikan. Sebagai contoh pada topik Trigonometri, guru dapat memberikan suatu proyek ke siswa untuk menghitung suatu bangunan/balok. Guru akan memberikan bimbingan kepada siswa mengenai alat yang akan mereka buat, (Moye \& Jr, 2012). Disini siswa akan diberikan kesempatan untuk mengeksplor bidang sains, teknik, seni dan matematika. Lalu, bagaimana dengan teknologi, (Hofstra et al., 2020). Pada bidang teknologi, siswa akan membuat teknologi sederhana dalam menyelesaikan tugas/proyek mereka. Selain itu, mereka juga akan membuat presentasi untuk menyampaikan hasil temuan mereka di depan kelas.

Melalui pembelajaran STEAM di kelas matematika, siswa akan lebih termotivasi untuk belajar terutama menekankan pada penggunaan teknologi, (Radziwill et al., 2015). Guru dan siswa dituntut untuk mengenal dan mencari tahu teknologi-teknologi apa saja yang bisa digunakan untuk menyelesaikan suatu proyek. Kedepan, siswa akan lebih siap untuk menghadapi tantangan globalisasi abad 21. Apalagi saat ini posisi pekerjaan yang lebih banyak dicari oleh perusahaanperusahaan adalah pada bidang STEAM, ("New Oxford American Dictionary," 2011),. Apabila kita mampu membekali siswa kita dengan pembelajaran STEAM sejak dini, maka siswa akan terlatih untuk menghadapi tantangan-tantangan yang terjadi, (Dubois et al., 1998).

Menurut penelitian (Wijaya et al., 2015) diketahui bahwa Pembelajaran berbasis STEAM dibutuhkan oleh siswa-siswi di Indonesia sebagai upaya untuk melatih kemampuan dan bakat mereka menghadapi masalah abad 21. Kompleksitas abad 21 dewasa ini menuntut kemampuan dari berbagai bidang, dan pembelajaran yang berbasis STEAM dapat menjadi persiapan dan latihan menghadapi semuanya. Desain, kreativitas, dan inovasi merupakan unsure art yang dipadukan pada yang awalnya STEM (Science, Technology, Engineering, and Mathematics) menjadi STEAM (penambahan unsur Art).

Penerapan STEM education telah berlangsung di beberapa negara, dan masing-masing memiliki bentuk beragam dalam hal penerapannya. Di Indonesia sendiri integrasi STEM sebagai pendekatan pembelajaran belum begitu populer. Hasil Penelitian (Nugroho et al., 2019) dengan judul STEM Education: Inovasi dalam Pembelajaran Sains menyebutkan bahwa seseorang yang memiliki literasi sains menggunakan kemampuan berpikir rasional dan logis serta bernalar, dan menggunakannya secara sistematik yang pada dasarnya merupakan inti dari literasi matematika. Literasi sains seseorang sangat terkait dengan literasi teknologi dan matematika.

Kendala yang dirasakan guru saat pengaplikasian STEAM di PAUD yaitu kurang adanya dukungan, tidak mengetahui manfaat STEAM, belum mendapatkan pemahaman mengenai 
STEAM serta APE belum memadai, (Munawar et al., 2019). Mengenai persepsi guru terhadap pembelajaran sosial finansial menggunakan metode STEAM dapat disimpulkan dari beberapa responden yang mengemukakan alasannya adalah Guru kurang merasakan manfaat STEAM di PAUD, (Nugraheni, 2019). Sebagaimana menurut (Wijaya et al., 2015) bahwa perkembangan sains dan teknologi yang sangat cepat tak dapat dihindari. Produk-produk berbasis pengetahuan (sains) sudah semakin banyak. Hal tersebut menuntut kemampuan siswa di masa depan agar menguasai tidak hanya sains dan teknologi tetapi juga seni (art) yang berhubungan dengan desain, kreativitas, dan inovasi. Pembelajaran yang berbasis STEAM (Science, Technology, Engineering, Art, and Mathematics) dapat membantu menstimulus kemampuan mereka menghadapi tantangan abad 21, (Maeda, 2013).

\section{KESIMPULAN}

Kesimpulan yang dapat dirangkum setelah penelitian ini, berdasarkan keseluruhan hasil kuesioner disimpulkan bahwa indikator yang menjadi tolok ukur keterbacaan kurikulum bermuatan STEAM dan terjadi peningkatan pengetahuan dan pemahaman guru setelah dilakukan ujicoba operasional model pengembangan kurikulum PAUD berbasis STEAM pada subjek penelitian yang telah dilakukan. Pembelajaran berbasis STEAM dibutuhkan oleh siswa-siswi di Indonesia sebagai upaya untuk melatih kemampuan dan bakat mereka menghadapi masalah abad 21

\section{DAFTAR PUSTAKA}

Apriliana, M. R., Ridwan, A., Hadinugrahaningsih, T., \& Rahmawati, Y. (2018). Pengembangan Soft Skills Peserta Didik melalui Integrasi Pendekatan Science, Technology, Engineering, Arts, and Mathematics (STEAM) dalam Pembelajaran Asam Basa. JRPK: Jurnal Riset Pendidikan Kimia. https://doi.org/10.21009/jrpk.082.05

Becker, K., \& Park, K. (2011). Effects of integrative approaches among science , technology, engineering, and mathematics ( STEM ) subjects on students ' learning : A preliminary metaanalysis. Journal of STEM Education. https://doi.org/10.1037/a0019454

DeJarnette, N. K. (2018). Implementing STEAM in the Early Childhood Classroom. European Journal of STEM Education. https://doi.org/10.20897/ejsteme/3878

Dubois, E., Yu, E., \& Petit, M. (1998). From early to late formal requirements: A process-control case study. Proceedings of the 9th International Workshop on Software Specification and Design, IWSSD 1998. https://doi.org/10.1109/iwssd.1998.667917

Hofstra, B., Kulkarni, V. V., Galvez, S. M. N., He, B., Jurafsky, D., \& McFarland, D. A. (2020). The diversity-innovation paradox in science. Proceedings of the National Academy of Sciences of the United States of America. https://doi.org/10.1073/pnas.1915378117 
Kementerian Pendidikan dan Kebudayaan Republik Indonesia. (2014). Permendikbud No. 137 Tahun 2014. Lampiran III. Implementation Science. https://doi.org/10.4324/9781315853178

Maeda, J. (2013). STEM + Art = STEAM. STEAM. https://doi.org/10.5642/steam.201301.34

Moye, J., \& Jr, W. D. (2012). The Status of Technology and Engineering Education in the United States: A Fourth Report of the Findings From the States (2011-12)-Results of a fourth. Technology and Engineering Teacher.

Munawar, M., Roshayanti, F., \& Sugiyanti, S. (2019). IMPLEMENTATION OF STEAM (Science Technology Engineering Art Mathematics) - BASED EARLY CHILDHOOD EDUCATION LEARNING IN SEMARANG CITY. CERIA (Cerdas Energik Responsif Inovatif Adaptif). https://doi.org/10.22460/ceria.v2i5.p276-285

New Oxford American dictionary. (2011). Choice Reviews Online. https://doi.org/10.5860/choice.48-3013

Nugraheni, A. D. (2019). Penguatan Pendidikan Bagi Generasi Alfa Melalui Pembelajaran Steam Berbasis Loose Parts Pada Paud. Seminar Nasional Pendidikan Dan Pembelajaran 2019.

Nugroho, O. F., Permanasari, A., \& Firman, H. (2019). Program Belajar berbasis STEM untuk Pembelajaran IPA: Tinjauan Pustaka, dengan Referensi di Indonesia. JURNAL EKSAKTA PENDIDIKAN (JEP). https://doi.org/10.24036/jep/vol3-iss2/328

Nurhikmayati, I. (2019). Implementasi Steam Dalam Pembelajaran Matematika. Jurnal Didactical Mathematics.

Radziwill, N., Benton, M., \& Moellers, C. (2015). From STEM to STEAM: Reframing What it Means to Learn. STEAM. https://doi.org/10.5642/steam.20150201.3

Riduwan. (2007). Skala Pengukuran Variabel-variabel Penelitian. In Alfabeta, Bandung.

Septiani, N. L. W., \& Yuliarto, B. (2016). Review-The Development of Gas Sensor Based on Carbon Nanotubes. Journal of The Electrochemical Society. https://doi.org/10.1149/2.0591603jes

Sugeng, H. M., Tarigan, R., \& Sari, N. M. (2019). Gambaran Tumbuh Kembang Anak pada Periode Emas Usia 0-24 Bulan di Posyandu Wilayah Kecamatan Jatinangor. JSK.

Wijaya, A. D., Dina, K., \& Amalia. (2015). Implementasi Pembelajaran Berbasis STEAM (Science, Technology, Engineering, Art, Mathematics) Pada Kurikulum Indonesia. Seminar Nasional Fisika Dan Aplikasinya. 